TRAMES, 2014, 18(68/63), 1, 3-17

\title{
THE EURASIAN UNION: DYNAMICS AND DIFFICULTIES OF THE POST-SOVIET INTEGRATION
}

\author{
Ardak Yesdauletova and Aitmukhanbet Yesdauletov \\ L. N. Gumilyov Eurasian National University, Astana, Kazakhstan, \\ and Columbia University
}

\begin{abstract}
This paper is dedicated to developments related to integration processes between Kazakhstan, Russia, and Belarus, which have collective existence as the Customs Union and the Single Economic Space. If matters progress as projected, within two years they will form a Eurasian Union modeled on the EU. The integration in Eurasia is developing with remarkable speed and has several obstacles to overcome. The first of these difficulties centers on economic relations. The second is the fear that Kazakhstan and Belarus have concerns about a potential loss of sovereignty, including a reduction in their capability to manage their internal and external affairs independently. The third set of problems relates to the smaller countries' desire to avoid dependence on one state, Russia, a situation which would lead to a rise in Russia's geopolitical role in the world. Also the Eurasian Union relates to counterbalance the strengthening of China's involvement in Central Asia policy.
\end{abstract}

Keywords: sovereignty, the Eurasian Union, the Customs Union, Kazakhstan

DOI: $10.3176 /$ tr.2014.1.01

\section{Introduction}

After the dissolution of the Soviet Union, almost all former members of the USSR signed the Treaty of the Commonwealth of Independent States (CIS) in December 1991. This agreement was the first step in a string of integration processes. However, as the president of Kazakhstan has remarked, "for objective and subjective reasons the CIS has not become the decisive integration structure of the post-Soviet space" (Nazarbayev 2011). Since the time of the formation of the CIS, the countries have made multiple efforts to establish various unions.

The main issue for the post-Soviet countries today is a creation of a new integration organization that would be adequate to the regional and global trends 
and challenges. After twenty years of independence Russia, Kazakhstan, and Belarus gained relatively rich experience in the formation of regional associations. But even now they are in the process of building a more perfect and influential one. On the one hand, integration is a demand of the internal conditions, stemming from the awareness of common approaches from each member of the organization. On the other hand, regional cooperation and integration is one of the main trends of global development in the twenty first century. For example, the European Union (EU), North Atlantic Free Trade Agreement (NAFTA), Association of South-East Asian States (ASEAN), Mercado Común del Sur (MERCOSUR) show the successful developments within their respective regions.

Studying features of the post-Soviet integration we attempt to determine difficulties that caused its ineffectiveness and failure up to this point in time. Also we estimate the future shape of the Eurasian Union that will be derived from the current organizations. At the same time the new Union will be created on the model of the European Union, especially in terms of political platform. However, it is a question about opportunities for Kazakhstan, Russia, and Belarus to form the real conditions for interrelations like in the EU. This issue concerns the sovereignty of these three members of the emerging organization. The European Union has difficulties concerning different approaches to a Common Foreign and Security Policy (CFSP), because of contradictions between big and small countries. One of the main problems with the EU is that it has had trouble establishing a common foreign policy because large and small countries do not share common interests in a CFSP. Therefore, it will not be easy to follow the EU way.

In our analysis, we identify three groups of problems that prevent the creation of a strong regional organization between Russia, Kazakhstan, and Belarus. The first group of obstacles refers to the economic aspects of integration processes. At least five issues stand in the way of successful integration. They are:

(1) There are too many economic sectors requiring too many regulations,

(2) The speed with which integration is proceeding,

(3) The failure of the three countries' foreign trade to orient itself toward the SES internal markets,

(4) The non-diversified nature of the SES countries' production and the high percentage of raw natural resources among their exports, and

(5) The adoption within the SES of higher tariffs than those in Kazakhstan and Belarus based on Russian tariffs.

A second group of challenges includes political issues, primarily the question of the sovereignty of the newly independent states. The creation of supranational organs will lead to a transformation of the post-Soviet space, because the transition is a new political organization, even though the stated goals are economic ones. The smaller partners, Kazakhstan and Belarus, will inevitably make concerted efforts to maintain their prerogatives in foreign and domestic affairs as well as their right, despite their considerably inferior size, to participate in the decisionmaking process. 
The third problem is a geopolitical issue. The Eurasian Union will inevitably have Russia, the largest state in the region, as its center. To the extent that the Union subsumes its smaller members, whose regional influence is relatively far less important, Russia's influence will only increase.

\section{The historical background of the Eurasian Union}

The first decade after the proclamation of independence, i.e. in the 1990s, all post-Soviet states faced the task of creating their own national economies. They aimed to enter the world community on the basis of their resources, on the one hand, and the assistance (including investments and consultations) of foreign countries on the other.

During that time, the initiative of Kazakhstan's President Nursultan Nazarbayev to create the Eurasian Union of the States in 1994 did not meet with wide support from the other countries in the CIS. The young countries, having recently declared their independence, were encouraged by the new open horizons they had after a long period of strict, centralized control.

Nevertheless, these countries gradually came to the conclusion that they could not develop successfully in the new environment on their own. Their independence required forming relations with their neighbors and other considerably more powerful countries. The post-Soviet states needed to unite in organizations in the last years of the twentieth century, because they had broken their previous economic ties and the whole chain between and among various members no longer existed. After the collapse of the USSR, these countries inherited very little, given the crisis state of the Soviet economy at the time of the Union's dissolution. Some attempts at integration appeared in Central Asia, but they were unsuccessful. The countries of the CIS created "other organizations with a more narrow focus" (Zabortseva 2012). They formed the Collective Security Treaty Organization (CSTO) in the military sphere, while in the economic field they created the Eurasian Economic Community (EurAsEC) and the Shanghai Cooperation Organization (SCO).

The Eurasian Economic Community was the real integrative force in the postSoviet space. Until the formation of the Customs Union, EurAsEC represented the highest level of integration in the new century. It was founded in Astana, Kazakhstan, on October 10, 2000. Five states (Russia, Kazakhstan, Belarus, Kyrgyzstan, and Tajikistan) signed the treaty that brought this organization into being.

The main tasks for these countries in the framework of this organization in the area of economic policy were as follows (Statement of the Heads of States 2009):

- conducting coordinated structural reorganization of the individual economies;

- drawing up and implementing joint programs of social and economic development;

- creating a common payment system; 
- providing for the interaction of the different currency and financial systems;

- creating equal conditions for industrial and entrepreneurial activities;

- forming a common market for transportation services as well as a unified transport system;

- establishing a common energy market;

- conducting joint research and development in the priority areas of science and technology;

- creating equal conditions for foreign investment;

- developing a unified multilateral and bilateral system for legal regulation and the establishment and operation of financial and industrial groups.

In 2003 the EurAsEC gained an observer status at the United Nations. This marked the recognition of the organization as an important actor in the post-Soviet region. "The importance of EurAsEC was shown by the more than 75 treaties signed by its five member-states. Most of these went into force" (Bykov 2009:15). The EurAsEC acted as an effective mechanism for solving economic and trade issues, and reconciling the interests of all members of the organization. EurAsEC has become a real world instantiation of Nazarbayev's Eurasian idea.

The next step was a decision to establish a Customs Union within the EurAsEC framework, with the Republic of Belarus, the Republic of Kazakhstan, and the Russian Federation as initial members. The Union came into being on January 1, 2010. As stated in the EurAsEC website, "In or the near future the establishment of the EurAsEC Customs Union and common economic space will enable the Community to become a rapidly developing organization for regional integration, able to ensure effective use of existing economic potential to raise the living standard of its peoples" (Website of the Eurasian Economic Community, 2013).Why did only three states form the Customs Union? Russia, Kazakhstan and Belarus have stronger economic potential than that of either Tajikistan or Kyrgyzstan. As mentioned above, post-Soviet countries decided to build the new organization on the model of the EU. Just as Germany and France were the twin locomotives for the European integration, Russia, Belarus, and Kazakhstan will serve as the essential core for the Eurasian integration. As Nazarbayev envisioned, "the microeconomic effect of the Customs Union quickly became obvious. In the first half of 2011, total trade increased by a third. Exports from Kazakhstan to Russia have increased by $60 \%$, to Belarus - more than 2.3 times" (Nazarbayev 2011).

The next step occurred on November 18, 2011, when the presidents of the founding states signed documents creating the Single Economic Space, which in its turn would prepare conditions for the Eurasian Union. "This is an important factor for regional stability, an improvement in the competitiveness of our economies that ensures technological advancement. After a year-and-a half of function under basis of these agreements we can see the benefits of this association for all the states" (Nazarbayev 2012). During the last 20 years participants in the Commonwealth of Independent States (CIS) have had a relatively rich experience 
along the path to integration. In October 2011 the Russian Premier, Vladimir Putin, published an article, "The New Integration Project for Eurasia - the Future that was Born Today" (Putin 2011). The article maintained that governments were ready to go to a more effective and higher level of regional integration. "Considering the process of regionalization of the world economy and politics in the twenty-first century, we are deepening the Eurasian integration. Kazakhstan, Belarus, and Russia have established the Common Economic Space. I would like to emphasize once again that this is an economic association. We are consistently moving forward towards the establishment of a Eurasian Economic Union" (Nazarbayev 2011).

\section{The economic dimension: the fast development in the old system.}

By 2015 the Eurasian Union is expected to reach the highest level of integration and put into place three economic policies: harmonization, functionality of supranational bodies, and the capacity to fulfill tasks that defend the members' common interests in world markets.

January 1, 2012 saw the launch of the Single Economic Space (SES). This will gradually create mechanisms for negotiations over regulation of economic issues, cross-border movements of capital, services, and migrations. The key goal of the Single Economic Space is to maintain the free movement of goods, capital, services, and people. This organization promotes competition and establishes equal conditions for businesses and investors, regardless of their country of origin. As it was pointed out by a director of the Eurasian Development Bank's (EDB) Centre for Integration Studies Eugene Vinikurov (2012:14), "The SES will reduce and ultimately eliminate the structures of national legislation at every stage of the business transaction, and it guarantees an overhaul of technical regulations and standards."

The SES will establish a solid base for a transition to the Eurasian Union. The participants have already accepted seventeen agreements for the formation of the Single Economic Space. In five years supranational bodies are scheduled to take on 175 national functions. The director of international projects of the Russian Strategies' Institute, Yuri Solozobov (2011) 'first of all, Russia, Belarus, and Kazakhstan had to coordinate the microeconomic indicators of their states. These are external debt, inflation, internal tariffs, and similar factors". The next step will be related to providing free movement of capital and labor. Then the "Eurasian troika' should change national policies in order to harmonize regulations of natural monopolies and form a common schedule of railroads tariffs. Further, the three countries should develop a system of single tariffs for oil and gas transport.

The founders of the Single Economic Space (to become the Eurasian Union in 2015) emphasized that their organization will follow the model of the European Union. Comparison of these two regional organizations does, of course, reveal some differences, especially in the speed with which the organizations developed. 
In Europe two countries (France and Germany) initially coordinated one sphere, the coal and steel industries in 1950. One year later, in April 1951 Belgium, France, Germany, Italy, Luxembourg and the Netherlands signed the Treaty of Paris establishing the European Coal and Steel Community (ECSC). It was the beginning of an enlarged common market for coal and iron ore which included six countries. The main achievement at that stage was removed custom duties and quantitative restrictions on these raw materials (Website European Union, 2013).

Thus, the first efforts which led to the eventual development of the EU were founded on the back of the closely related coal and steel industries. The coal and steel industries were, of course, very important for reconstruction after the Second World War. The ECSC represented the first supranational body based on equal rights of its member-states. From this beginning, the integration process developed gradually, step by step over a number of decades.

In contrast, the development of the Eurasian Union (today it is Single Economic Space) has been moving very fast, indeed: From October 2000 (EurAsEC) to 2010 (the Customs Union) to 2011 (the Declaration of Eurasian Economic Integration) to 2012 (SES) the members have taken four steps to integration. The presidents are clearly pushing the integration process at a rapid pace. Consequently, these frequent changes made it impossible to evaluate or even measure any tangible results of the previous stage before the integration moved onto its next phase. As a result, it is important to analyze not only positive, but also negative experiences. Doing so provides opportunities to consider the lessons from the past and change course in the future, if necessary.

The SES embraces wide swaths of its members' economies, from railroads to a common currency. It is thus appropriately called 'all and at once.' It is important to consider not only the range and number of the defined tasks and the short period of their realization but also the components of integration. In this context the most obvious components are trade and manufacturing. The main challenge for integration is a lack of diversification. The General Director of the Political Conjuncture, a company specialized on political, sociological, and historical analysis of contemporary Russia, Sergei Mikheev (2006) emphasized that "Diversification is on the lowest level. In Russia the business elite is concerned with the sale of raw materials (primarily fuel). In Kazakhstan and Ukraine things are proceeding in the same vein." Ukrainian industry mainly sells products that are higher up the chain of production, while in Kazakhstan mining industries have historically been more developed. In accordance with his opinion, the economies of Russia, Kazakhstan, and Belarus are oriented toward external markets, i.e. export to other countries. "The elites of those states seek to avoid "too much economic dependence on other nations - mainly Russia" (Mikheev 2006). Only Belarus considers the post-Soviet space its priority in trade. This obviously stems from its lack of resources that are in demand in the world marketplace.

Kazakhstan illustrates this point. Possessing significant resources of oil, gas, and metal ore, it sells natural resources to the non-CIS countries. Official data prove the statement: "In accordance with the custom statistics and the RK 
Statistics Agency during the period from January to September 2011, the basic customers for Kazakhstan's goods were non-CIS countries, which account for $85.6 \%$ (US\$ 56.3billion) of the country's total exports. Thus, the CIS countries' share of Kazakhstan's exports is only $14.4 \%$ (US\$ 9.5 billion).

The main products for export from Kazakhstan are (Overview of Kazakhstan's foreign trade, 2011):

- Fuel oil - 79.5\% (US\$ 44, 789.3million).

- Ferrous metal - 6.1\% (US\$ (3, 420.2 million);

- Ores, slag, and ash $-2.4 \%$ (US\$ 1, 349.1 million);

- Copper and copper products - 3.5\% (US\$1, 950.1million);

- Inorganic chemical products $-2.9 \%$ (US\$ $1,636.7$ million);

- Natural pearls - 2.2\% (US\$ 1, 265.1 million).

Mass media announces that bilateral trade relations are successfully developing within the Commonwealth of Independent States. Kazakhstan has a healthy trade with Russia, Russia with Ukraine and Belarus, and so on. To a certain degree this suggests that there is groundwork on which to base integration. However, the majority of exports include raw materials traded to the third parties. Research in Kazakhstan highlighted the question of manufacturing quality there. Darya Mukhamedzhanova (2007), a leading expert of the Institute of World Economy and Policy at the Foundation of the First President of Kazakhstan (IWEP), wrote, that this economic situation "does not really make it possible to talk about the 'production (i.e. manufacturing) model' of the integration. In addition each of the state companies fights for its own access to international markets first and then considers the interests of its partners."

Furthermore, Russia has the same problem. It is noteworthy that, in the reorientation of foreign trade, Russia is leading among the CIS countries. Russia proclaimed the Commonwealth of Independent States as its foreign relations priority, but this declaration has not been supported by its actions. "For Russia, the preferred direction is west, where the majority of its exports fetch higher prices, payments are made on time, and the quality goods it receives in return are better" (Mukhamedzhanova 2007:70).

This situation received some notice from the Minister of Trade for the Eurasian Economic Commission, Andrei Slepnev, during his visit to Astana in April 2012. He emphasized competitiveness and the correct choice of partners as necessary for the building of effective cooperation. Russia is worried about the survival of some of its national ventures. "But transnational unions are formed in order to increase the capacity of their constituents' national economies, so goods have to be competitive not only in domestic but also in the foreign markets. Without this, ventures simply cannot survive without artificial support" (Polonskaya 2012:1).

Complicating the economic dimension of the integration processes is the issue of tariffs. The tariffs have been established in such way that Russian tariffs are higher than those in Kazakhstan and Belarus. As Alexander Cooley wrote, liberalizers viewed the integration "as locking Kazakhstan into Russia's embrace and potentially delaying its accession into the WTO; some consumer groups 
complained of the higher Russian tariffs, especially on imported cars" (Cooley 2012:62).

In conclusion, at least five issues stand in the way of successful integration. They are:

(1) Too many economic sectors requiring too many regulations,

(2) The speed with which integration is proceeding,

(3) The failure of the three countries' foreign trade to orient itself toward the SES internal markets,

(4) The non-diversified nature of the SES countries' production and the high percentage of raw natural resources among their exports, and

(5) The adoption within the SES of higher tariffs than those in Kazakhstan and Belarus based on Russian tariffs.

\section{Sovereignty of the states in the framework of the Eurasian Union}

No doubt, integration is a common trend in contemporary international affairs. Eurasian nations cannot ignore this dominant movement, as the world markets become increasingly globalized. The idea of the Eurasian Union requires overcoming economic obstacles, especially given the conditions in crisis-ridden Europe. The Eurasian Union with the big internal markets of the member-states will provide tools for countering economic crises farther west.

Simultaneously, it is obvious that the output which has not been in demand on world markets can be successfully sold in the territories of the former Soviet Union. In addition, the former Soviet republics represent a prospective source of labor for each other. The official statistics on migration flows demonstrates how much the three post-Soviet countries are dependent on each other. Russia and Kazakhstan are the main recipients of migration from Central Asian states. Nowadays these two factors (labor and migration) are the only indisputable arguments for integration.

"However, the integration processes run into difficulties around a coordinated monetary policy" (Mikheev 2006). In this regard, those who conduct business and face innovations in the law and regulations in the real economy emphasize that differences in monetary operations present the biggest obstacles to the creation of a single market. After proclaiming independence all post-Soviet states adopted their own currencies in the mid-1990s. A national currency is a powerful symbol of state sovereignty. During trade operations and any other financial transactions, the CIS countries, following international practice, convert their national currencies into US dollars. The CIS states need to conduct all operations in both US dollars and in the national currencies (for example, the Russian ruble, Belarusn ruble, and Kazakh tenge). Also, each state has its own national tariff and duties rates. All these differences in accounting practices slow down procedures and transactions. National currencies became a more important issue between states that established the common economic space. 
Nonetheless, the main issue being debated, besides the aspects of timing, speed, and range of defined tasks, is the issue of a supranational body. The formation of such a structure will mean reducing the authority of the member states' government to conduct foreign trade and manage internal production.

The creators of the Eurasian Union want to base the new integrated organization on the model of the EU, especially in the building of supranational bodies. The first stage for transition to such bodies was the establishment of the Eurasian Economic Commission (EEC), which replaced the Commission of the Customs Union on July 1, 2012. The Eurasian Economic Commission has a two-level structure: a Council of the Commission and a Board. The Council will conduct the general regulation of integration processes within the Customs Union and the Single Economic Space. The Board will act as the executive body and will implement and administrate suggestions for further integration.

In accordance with the words of the Vice-Minister of Economic Development and Trade, Timur Suleimenov, Kazakhstan and Belarus will have equal representation in the Eurasian Economic Commission. However, financing of the Commission will be carried out on the basis of the budget generated by assessed contributions from the three parties: for Belarus $-4.7 \%$, for Russia $-87.97 \%$, and for Kazakhstan -7.33 \% (Kazakhstan's Parliament ratified the Treaty, 2011).

The agreement provided for an equal distribution of votes both in the Council and in the Board: one representative has one vote. The Vice-Minister also emphasized that "all decisions of the council will be made by consensus. In case a consensus is not reached, any of the Council members may refer the matter to the Supreme Eurasian Economic Council, which has equal status to the heads of governments and the heads of state" (Kazakhstan's Parliament ratified the Treaty on the Eurasian economic Commission, 2011).

This procedure, in comparison with the procedure adopted in the Eurasian Economic Community (EurAsEC), is a step forward because it gives relatively more rights to smaller partners of the organization. In the EurAsEC, which consists of five member-states, there is an unequal distribution of votes. The rules of the EurAsEC state that "contracting parties shall correspond to their respective prorated contributions to the Community Budget and shall be (Agreement on the foundation of the Eurasian Economic Community, 2000):

The Republic of Belarus - 20 votes;

The Republic of Kazakhstan - 20 votes;

Kyrgyz Republic - 10 votes;

The Russian Federation - 40 votes;

The Republic of Tajikistan -10 votes.

Therefore, the Eurasian Economic Commission may come to represent the first truly supranational institution in the region's 20 years of post-Soviet reintegration attempts. The main points pertaining to the supranational bodies are, first, the equal participation of all parties in the decisions on and distribution of a budget and, second, the question of how widespread the powers of these supranational 
bodies will be, i.e. whether there will be a balance between weak and strong participants.

In a November 2011 newspaper article, Vladimir Putin insisted that there was no talk of re-forming the USSR, arguing that it would be naive to copy what had been abandoned in the past (BBC, 2011). But despite the statements from the leaders of Russia, many ordinary people as well as social scientists are not sure whether real equality will be possible. Even at the end of 2012, the Eurasian Economic Commission had more than 170 functions, and not only in the sphere of customs and tariff policy. This body will therefore be responsible for depositing and allocating the budgets which will be formed upon the basis of all three countries' import duties, approval of technical regulations, sanitary and veterinary norms, regulation of transport and transportation issues, energy, industrial and agricultural subsidies, states procurements, labor migration, monetary policy, and financial markets. "The Commission will solve many other 'sectoral' issues which gradually will move from the national governments to the EEC" (Arešev 2011).

Gradually, all important matters will be in the hands of the Eurasian Economic Commission, in other words, at the supranational level. This Commission will not be under the national governments. Consequently, the national governments will hand over a significant portion of their authority.

The EEC will include one vice-premier, and the Board will include three representatives from each member-state. The Board's decisions will be directly applicable on the territories of these countries. However, it is possible that the necessary requirements for citizens to obey the supranational body may raise conflicts with the constitution of each state; such matters will be solved by a referendum.

Therefore, creating truly equal conditions for a strategic partnership is an essential basis for implementation of the Eurasian Union project. "The slogan "do not step on the gas" is a literal and figurative imperative, first of all, for Russia. The establishment of too many preferences for Russian companies can destroy the whole apparatus and the mutual trust among the partners" (Solozobov 2011).

\section{Strategic ambitions of the Eurasian Union.}

The Single Economic Space, which in the near future will be transformed into the Eurasian Union, has strategic aims as well as economic ones. It will affect regional international relations. Some experts maintain that Russia has lost influence in Central Asia. Professors Martin Spechler and Dina Spechler (2013:1) for example, argue that, "unable to modernize its economy and armed forces, Russia has failed to achieve most of the main objectives (excluding NATO, regaining trade exclusivity, ending drug, arms, and terrorist infiltration) it has set for itself in the 'near abroad."'. Marlene Laruelle and Sebastien Peyrouse (2013:19) both share this opinion about the diminution of Russia's influence on Central Asian countries. However, the Kremlin continues to conduct an active 
policy aimed at maintaining effective tools to influence the Central Asia region. First regional associations such as CU and the SES will strengthen the influence of Russia on the Central Asian countries. Kyrgyzstan intends to join these organizations in near future. Secondly, in the energy sector, which is the main vector in foreign policy of Central Asian countries and Russia, the latter has more advantages. The failures of 'Nabucco' and 'Trans-Caspian' gas pipelines shows the possibilities of the northern neighbor to reach its aims. Thirdly, in the sphere of providing security in the Central Asian region, Russia will inherit the legacies of problems after a withdrawal of NATO from Afghanistan. Russian politicians and scholars worry about challenges from its southern borders. That is why Russia has been eager in recent years to strengthen its position in the Central Asian republics.

The creation of a newly integrated regional block will cause a "shift in the geopolitical context". Although the three members of the Eurasian Union are declared equal in the signed documents we think that in reality it will be a union of uneven partners. Andreas Umland (2011), the German scholar, has emphasized: "First and foremost, there exists a fundamental geo- and demographic disparity as well as military imbalance between Russia, on the one side, and the rest of the envisaged Union members, on the other". Russia is far larger and militarily more potent than any of the other member states of the Eurasian Union. Also this state would exceed, in terms of size and power, the sum of the resources of all putative future participants of the Union taken together. This incongruence would be most prevalent in the case of the creation of a political union. It may lead to real challenges for the current Customs Union.

Table 1 shows significant differences among the CU/SES states on various parameters (The World Bank, 2012).

Russia leads the Customs Union and the Single Economic Space in terms of territory and population size. In addition, its military and political weights far exceed that of Kazakhstan and Belarus. Therefore, in its current and future organizations the Eurasian Union will hardly be a union of equal partners. The creation of this supranational body causes tension in relations between Russia and the two other countries. Although the creators of the Eurasian Union insist that this new alliance will be built on the experience of the EU there are doubts as to how decision-making will be conducted at the supranational level. Among EU members, Germany has a dominant position because it is the economically most

Table 1. Macroeconomic Indicators of the Customs Union Countries, 2011

\begin{tabular}{lcccc}
\hline & Russia & Kazakhstan & Belarus \\
\hline Population & $142,960,000$ & $16,558,676$ & $9,473,000$ \\
GDP & $\$ 1,857,769,676,143$ & $\$ 188,049,986,359$ & $\$ 55,132,080,402$ \\
GDP growth & $4.3 \%$ & $7.5 \%$ & $5.3 \%$ \\
$\begin{array}{l}\text { Official change rate of national } \\
\text { currency to USD }\end{array}$ & 29.38 & 146.62 & $4,974.63$ \\
\hline
\end{tabular}


powerful country with the largest population in the European Union. On the other hand, in military sphere Germany does not exceed other European countries. Thus, Germany does not dominate the EU to the same degree that Russia dominates integration organizations in the former Soviet space as Umland states, "Apart from the Berlin Bundeskanzleramt, the Élysée Palace in Paris and Number 10 Downing Street in London constitute formidable power centers within the EU. These actors, among other factors, balance the FRG's economic power, and have been forcing the German Chancellors to seek support, make compromises, and create alliances when they wanted to implement a certain policy" (Umland 2011). Umland has expressed doubt in the likelihood of such a style of management in the emerging Eurasian Union.

The other aim of the creation of the Eurasian Union is reducing the growth of the impact of the People's Republic of China. According to Laruelle and Peyrouse, "Moscow indeed has lost its control over the Central Asian economies, especially with the rise of China as a major trading partner of the region. Only control over some hydrocarbon exports and strategic partnership, for example in the civilian nuclear sector, seems set to continue over long term" (Laruelle and Peyrouse 2013:19). China is the most dynamic developing state not only in the region but in the world. The main directions of its policy toward Central Asia are energy and trade. China is the number one consumer of energy in the world, even surpassing the U.S.A. Like a huge dragon, the PRC is pulling the states of Central Asia into its 'orbit' of policy. The influential regional organization SCO is becoming the tool of China's policy. Russia intends to create a union which will be a counterbalance to China's efforts.

\section{Conclusion}

In sum, the proposed Eurasian Union has a convincing rationale for its existence. In a globalized world the role of international organizations continues to grow. Darya Mukhamedzhanova (2011: 25) wrote, "The main need for effective economic management in Kazakhstan and in other post-Soviet countries is the pressing necessity of interaction with international bodies and the strengthening of institutional structures, which provide connections between global obligations and national priorities."

Many major countries as well as smaller ones have joined one larger international organization or another. Even big states such as the United States and those in Western Europe conduct at least some of their foreign and domestic policies as part of a larger integrated block. Post-Soviet states also made several attempts to form similar organizations during the twenty-one intervening years since the USSR's unraveling, but those efforts were for the most part unsuccessful. The leaders of the CIS countries are learning from other countries' experience and using the lessons it provides in order to improve their new regional structures. But in the case of the Eurasian Union, which pretends to be more ambitious and 
advanced that it actually is, there remain both old and new obstacles that hinder its realization.

The obstacles derive in part, first, from the current economic system. All of the economies need changes in their structures, diversification of production, and widening of the scope of foreign trade, which at the moment is oriented toward markets in the West or East but not toward the group's internal markets.

A second group of problems includes political issues, primarily the question of sovereignty of the newly independent states. The creation of supranational organs will lead to a transformation of the post-Soviet space, because the transition is to a new political organization, even though the stated goals are economic ones. The smaller partners, Kazakhstan and Belarus, will inevitably make concerted efforts to maintain their prerogatives in foreign and domestic affairs as well as their right, despite their considerably inferior size, to participate in the decision making process.

Finally, a third set of challenges is connected to geopolitical issues. The Eurasian Union will inevitably have Russia, the behemoth of the region, as its center. To the extent that the Union subsumes its smaller members whose regional influence is relatively far less important, this will only increase the influence of Russia. When one member state has both vastly greater resources and population than the other two combined, inequality is almost certain, and integration may possibly serve the interests of only one side of this determinedly un-equilateral triangle.

\section{Acknowledgements}

The authors would like to thank Elise Giuliano, a professor of the Harriman Institute at Columbia University, for her useful comments and suggestions on previous versions of the article.

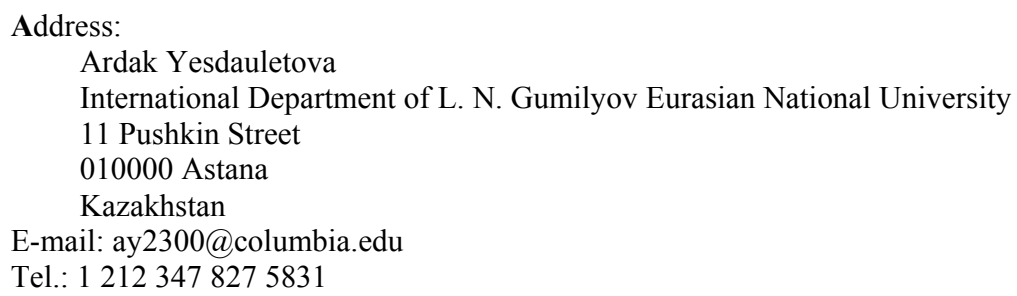

\section{References}

Agreement on the foundation of the Eurasian Economic Community (2000). Article 13, The decision-making procedure (Dogovor ob uchreždenii Evrazijskogo ekonomičeskogo soobščestva). Available online at <http://www.worldtradelaw.net/fta/agreements/ eaecfta.pdf $>$. Accessed on 01.08.2013. 
Arešev, Andrej (2011) The Eurasian Union: the intention and the risks. (Yevrazijskij sojuz: namerenija $i$ riski). Available online at $<$ http://www.stoletie.ru/print.php?ID $=116030>$. Accessed on 01.08.2013.

BBC News (2011) Europe Russia sees union with Belarus and Kazakhstan by 2015. Available online at $<\mathrm{http} / / / w w w . b b c . c o . u k / n e w s / w o r l d-e u r o p e-15790452>$. Accessed on 01.08.2013.

Cooley, Alexander (2012) Great games, local rules: the new great power contest in Central Asia. New York, NY: Oxford University Press.

Bykov, Alexandr Naumovich (2009) Post-Soviet space: strategies of integration and the new challenges of globalization (Postsovetskoye prostranstvo: strategii integratsii $i$ novyye vyzovy globalizatsii). St.-Petersburg: Aleteya.

Kazakhstan's Parliament ratified the Treaty on the Eurasian Economic Commission (Parlament Kazakhstana ratificiroval Dogovor o Evrazijskoj ekonomičeskoj komissii) (2011). Kazakhstan Today. Available online at <http://www.kt.kz/?lang=rus\&uin=1133168193\&chapter= 1153549380>. Accessed on 01.08.2013.

Laruelle, Marlene and Sebastein Peyrouse (2013) Globalizing Central Asia: geopolitics and the challenges of economic development. Armonk, NY: M.E. Sharpe.

Mikheev, Sergei (2006) Post-Soviet space: elites are against integration. (Postsovetskoje prostranstvo: elity protiv integracii). Available online at $<\mathrm{http}$ //www.apn.kz/publications/ article 7698.htm>. Accessed on 01.08.2013.

Mukhamedzhanova Darya (2007) "Economic preconditions of regional integration in the post-soviet Space" (Ekonomicheskiye predposylki regionaloi integratsii na postsovetskom prostranstve) Journal of Kazakhstan in the Global Processes (Kazakhstan v global'nyx processax) 4, 138149.

Mukhamedzhanova Darya (2011) Kazakhstan and iInternational integration presses (Kazakhstan I mezhdunarodnyye integratsionnyye protsessy). Almaty: KISI.

Nazarbayev, Nursultan (2011) Eurasian Union: from idea to the history of the future. (Evrazijskij Soyuz: ot idei $k$ istorii buduščego). Izvestija-Kazakhstan. Available online at <http:// www.akorda.kz/ru/speeches/articles/evraziyskiy_soyuz>. Accessed on 01.08.2013.

Nazarbayev, Nursultan (2012) Remarks by President Nursultan Nazarbayev at a meeting with heads of the diplomatic missions accredited in Kazakhstan. (Vystuplenije Prezidenta Respubliki Kazaxstan N.A. Nazarbayeva na vstreče s glavami zarubežnyx diplomatičeskix missij, akkreditovannyx v Kazaxstane.02.03.2012 g.) Available online at <http:/www.akorda.kz/en/page/ remarks-by-president-sursultan-nazarbayev-at-a-meeting-with-heads-of-the-diplomaticmissions-accredited-in-kazakhstan-2-03-2012_1341926694>. Accessed on 01.08.2013.

Overview of Kazakhstan's foreign trade in January-September 2011 (2011) (Obzor vnešney torgovli Kazaxstana za yanvar' - sentyabr' 2011). group-global.org/storage_managel download_file/887

Polonskaya, Yliya (2012) Competition defines development. (Razvitije opredeljaet konkurencija). Kazaxstanskaja Pravda.

Putin, Vladimir (2011) The new integration project for Eurasian - a future that is born today. (Novyj integracionnyj proekt dlja Evrazii - buduščeye, kotoroye roždaetsja segodnja.) Available online at $<$ http://izvestia.ru/news/502761\#ixzz1s03GRcgw $>$. Accessed on 01.08.2013.

Solozobov, Yuri (2011) "Eurasian Union: from idea to practice." (Evrazijskij Soyuz: ot idei $k$ praktike). Geopolitika 13, 7-1.

Spechler, Martin and Spechlet Dina (2013) "Russia's lost position in Central Eurasia". Journal of Eurasian Studies 4, 1-7.

Statement of the Heads of States of the Republic of Belarus, the Republic of Kazakhstan, the Kyrgyz Republic, the Russian Federation and the Republic of Tajikistan on the Establishment of the Eurasian Economic Community (2009). (Zajavlenie glav gosudarstv Respubliki Belarus', Respubliki Kazaxstan, Kirgizskoj Respubliki , Rossii i Respubliki Tadžikistan ob učrezdenii Evrazijskogo ekonomičeskogo soobščestva). Available online at $<\mathrm{http} / /$ www.evrazes.com/ docs/view/94>. Accessed on 01.08.2013.

Vinikurov, Eugene (2012) "The Custom Union and the Single Economic Space: Toward the Eurasian Economic Union". Journal of EDB Eurasian Integration Yearbook 2012. Available online at 
$<$ http://www.eabr.org/general//upload/CII\%20-\%20izdania/Yerbook-2012/a_n5_2012_05.pdf $>$. Accessed on 01.08.2013.

Website European Union. History of the European Union. Available online at $<$ http://europa.eu/abouteu/eu-history/1945-1959/1952/index_en.htm>. Accessed on 01.08.2013.

Website of the Eurasian Economic Community. Available online at $<$ http://www.evrazes.com/en/ about/>. Accessed on 01.08.2013.

Website World Bank, 2013. Available online at <http://web.worldbank.org/WBSITE/EXTERNAL/ COUNTRIES/0,,pagePK:180619 theSitePK:136917,00.html >. Accessed on 01.08.2013.

Umland, Andreas (2011) Why Russia-led post-Soviet integration has little prospects. Available online at <http://www.academia.edu/1157293/Why_Russia-led_Post-Soviet_Integration_ Has_Little_Prospects>. Accessed on 01.08.2013.

Zabortseva,YYelena (2012) "From the "forgotten region" to the "great game" region: on the development of geopolitics in Central Asia". Journal of Eurasian Studies 3, 168-176. 
